\title{
Phytohaemagglutinin induced proliferation of lymphocytes from patients with rheumatoid arthritis and iron deficiency
}

\author{
REX J POLSON, ${ }^{1}$ ADRIAN BOMFORD, ${ }^{1}$ HEDLEY BERRY ${ }^{2}$
} AND ROGER WILLIAMS

From the 'Liver Unit and the ${ }^{2}$ Department of Rheumatology, King's College Hospital, Denmark Hill, London

SUMmARY The response of peripheral blood lymphocytes to stimulation by mitogens such as phytohaemagglutinin (PHA) is commonly depressed in both rheumatoid arthritis and irono deficiency, and as many rheumatoid patients are anaemic with evidence of abnormal iron metabolism it is possible that the same mechanism underlies the observed suppression in both conditions. In the present study the mitogenic response to PHA of lymphocytes from three rheumatoid patients, who were also iron deficient, and two healthy controls has been shown to beco significantly less in iron deficient than iron containing media $(p<0 \cdot 001)$. In addition, irono deficient sera from these patients reduced the PHA induced proliferation of lymphocytes from aD normal subject $(\mathrm{p}<0 \cdot 01)$, an effect which was prevented by prior addition of iron to these serums samples. In iron containing media lymphocytes from five patients and two controls showed no5 difference in their response to PHA for both the minimum mitogen concentration whicho enhanced transformation and the peak $\left[{ }^{3} \mathrm{H}\right]$ thymidine uptake; but patients' lymphocytes showed significantly less response to PHA concentrations of 5 and $10 \mathrm{mg} / 1(\mathrm{p}<0.02)$, resulting in $\overrightarrow{2 \overrightarrow{0}}$ reduction in the area under the dose response curves up to $20 \mathrm{mg} / \mathrm{l}(\mathrm{p}<0.05)$. These findings show both that iron deficient sera can impair PHA induced lymphocyte transformation and that lymphocytes from iron deficient rheumatoid patients have impaired responsiveness to PHA. Iron is known to be required intracellularly for the enzyme ribonucleotide reductase, which is important for DNA synthesis, and reduced activity of this enzyme could explain these observed effects.

In patients with rheumatoid arthritis the response of peripheral blood lymphocytes to the mitogens phytohaemagglutinin (PHA) and concanavalin A (con A) is fairly consistently depressed. ${ }^{1-5}$ Several studies have also suggested that after successful treatment with remission inducing agents the lymphocyte response will return to normal, ${ }^{4-6}$ though the mechanism which underlies this recovery is not clear. Animal studies have shown that iron deficiency will reduce lymphocyte responsiveness to mitogens; a result which may be due to inadequate concentrations of circulating transferrin bound iron rather than to an intrinsic defect in the cells themselves. ${ }^{7}$ As impaired iron metabolism and even

Accepted for publication 20 December 1987.

Correspondence to Dr Roger Williams, Liver Unit, King's College Hospital, Denmark Hill, London SE5 9RS. overt iron deficiency is a frequent complication of rheumatoid arthritis, ${ }^{8-11}$ which is often corrected byo the therapeutic suppression of disease activity, it is possible that changes in iron availability mayos account for the observed response to mitogen stimulation of lymphocytes from these patients.

\section{Patients and methods}

Five patients with active rheumatoid arthritis, whof were also markedly iron deficient (Table 1), and two healthy controls with normal iron stores weres studied. All gave informed consent to the study $\overrightarrow{\mathbb{Q}}$ which received local ethical committee approval.

All solutions were prepared in iron free plastic of acid washed glassware using glass distilled deionised water and, where necessary, sterilised by filtration? 
Table 1 Patient details

\begin{tabular}{llllll}
\hline $\begin{array}{l}\text { Patient } \\
\text { No }\end{array}$ & $\begin{array}{l}\text { Agel } \\
\text { sex }\end{array}$ & $\begin{array}{l}\text { ARA }^{*} \\
\text { criteria }^{\prime 2}\end{array}$ & $\begin{array}{l}\text { Haemoglobint } \\
(g / l)\end{array}$ & $\begin{array}{l}\text { Serum } \\
\text { iron/ } \\
\text { TIBC } \\
(\mu \mathrm{mol} / \mathrm{l})\end{array}$ & $\begin{array}{l}\text { Ferritin' } \\
(\mathrm{mg} / \mathrm{l})\end{array}$ \\
\hline 1 & $42 \mathrm{~F}$ & $7 / 11$ & 74 & $3 / 74$ & 1 \\
2 & $64 \mathrm{M}$ & $7 / 11$ & 69 & $2 / 78$ & 1 \\
3 & $63 \mathrm{M}$ & $7 / 11$ & 98 & $3 / 60$ & 1 \\
4 & $66 \mathrm{~F}$ & $8 / 11$ & 97 & $6 / 55$ & $39 \ddagger$ \\
5 & $65 \mathrm{M}$ & $7 / 11$ & 126 & $7 / 58$ & 2
\end{tabular}

*ARA = American Rheumatism Association; TIBC $=$ total iron binding complex.

†Haemoglobin: normal range for men $130-160 \mathrm{~g} / \mathrm{l}$; for women 120-150 g/l (World Health Organisation criteria for anaemia: for men $<130 \mathrm{~g} / 1$, for women $<120 \mathrm{~g} / \mathrm{l})$; serum iron/TIBC: normal range $13-32 / 45-70 \mu \mathrm{mol} / \mathrm{l}$; ferritin: normal range $13-250 \mathrm{mg} / \mathrm{l}$. (Reduced iron stores in rheumatoid arthritis suggested by ferritin $<12.0 \mathrm{mg} / \mathrm{l}^{13}$ )

$¥$ Serum ferritin of this concentration, despite a low serum iron, probably related to the inflammatory process as this patient had an erythrocyte sedimentation rate $>120 \mathrm{~mm} / \mathrm{h}$. Iron deficiency is confirmed by a transferrin saturation below $16 \% .^{14}$

Serum was stored at $-20^{\circ} \mathrm{C}$ and filtered through a $0.02 \mu \mathrm{m}$ filter (Millipore (UK) Ltd, Harrow, Middlesex, UK) before use.

\section{POOLED NORMAL SERUM}

Venous blood was taken from 10 healthy subjects (nine men) with normal iron stores and the serum separáted by centrifugation ( $2600 \mathrm{rpm}$ for 10 minutes) and pooled. The complement present was inactivated by heating to $56^{\circ} \mathrm{C}$ for 30 minutes.

\section{IRON DEFICIENT SERUM}

Samples of fetal calf serum (Gibco Europe Ltd, Uxbridge, Middlesex, UK) and pooled human serum were dialysed overnight against $100 \mathrm{mM}$ sodium citrate solution ( $\mathrm{pH} \mathrm{4.5)}$ and then dialysed extensively against iron free water.

\section{IRON DEFICIENT RPMI 1640}

Chelex (1 g; Sigma Chemical Co, Poole, Dorset, UK) was added to $20 \mathrm{ml}$ RPMI 1640 culture medium (Gibco) containing $120 \mathrm{mg} / \mathrm{l}$ benzylpenicillin, $100 \mathrm{mg} / \mathrm{l}$ streptomycin; and $100 \mathrm{mg} / \mathrm{l}$ amphotericin B, and turned end over end for 60 minutes at $20^{\circ} \mathrm{C}$. The supernatant was decanted off and $1.8 \mathrm{mM}$ calcium chloride and $0.8 \mathrm{mM}$ magnesium sulphate were added back to the medium.

\section{HOMOLOGOUS PATIENT SERUM}

Serum was obtained from three of the rheumatoid patients, and $0.5 \mathrm{mg}$ ferrous ammonium sulphate was added to a $10 \mathrm{ml}$ aliquot from each to saturate the transferrin; the remaining serum was stored untreated.
ISOLATION AND CULTURE OF CELLS

Venous blood was taken into heparinised dextran, the erythrocytes sedimented under gravity, and the peripheral blood mononuclear cells were isolated by centrifuging the plasma through Ficoll (Pharmacia, Milton Keynes, Buckinghamshire, UK). ${ }^{15}$ After washing three times in Chelex treated iron deficient RPMI 1640 the cells were counted in a haemocytometer. Viability was determined by exclusion of $0.2 \%$ trypan blue, and the cells were then suspended at a concentration of $10^{6}$ cells $/ \mathrm{ml}$ in either Chelex treated or untreated RPMI 1640 containing $10 \%$ $(v / v)$ serum which was either fetal calf or human serum pretreated as indicated. The cells were cultured in flat bottomed microtitre plates (Dynatech Laboratories Ltd, Billingshurst, Sussex, UK) with each well containing 200000 cells, under a humidified atmosphere of $5 \% \mathrm{CO}_{2} /$ air at $37^{\circ} \mathrm{C}$ for 66 hours, and PHA (Sigma) was added in varying concentrations (range $0-50 \mathrm{mg} / \mathrm{l}$ ) as appropriate. The effects of iron deficient and iron containing media on PHA induced mitogenesis were assessed using lymphocytes from three patients (Nos 2, 4, and 5), while cells from all five patients were cultured in iron containing media to obtain PHA induced dose response curves. Proliferative response was assessed by incubation with $\left[{ }^{3} \mathrm{H}\right]$ thymidine (Amersham International plc, Aylesbury, Buckinghamshire, UK), 37 kBq/well, for four hours. The cells were harvested with a Skatron cell harvester (Flow Laboratories, Rickmansworth, Hertfordshire, UK) and the radioactivity counted in a Packard liquid scintillation counter.

Results for lymphocyte transformation are expressed as either $\mathrm{cpm} /$ well, or mean transformation index (cpm/well after stimulation with PHA divided by the $\mathrm{cpm} /$ well without mitogen) and compared using Wilcoxon's matched pairs signed ranks test for non-parametric data. In addition, the results were converted to $\log _{10} \mathrm{cpm}$ and compared using Student's $t$ test for paired and unpaired data as appropriate. Two tailed tests were used throughout.

\section{Results}

Lymphocyte viability as assessed by trypan blue exclusion was always greater than $98 \%$ before culture and greater than $95 \%$ in both iron containing and iron deficient media at the end of the culture period. The iron content of the citrate treated sera as determined by a standard laboratory semiautomated process (and based on the method of Young and Hicks ${ }^{16}$ ) was found to be less than $2 \mu \mathrm{mol} / \mathrm{l}$, while the Chelex treated culture media contained less than $2 \mu \mathrm{g} / \mathrm{l}$ as determined by flameless atomic absorption spectrophotometry.

When all three iron deficient incubation media are considered together PHA induced mitogenesis 
Table 2 Effects of iron deficient media on lymphocyte transformation

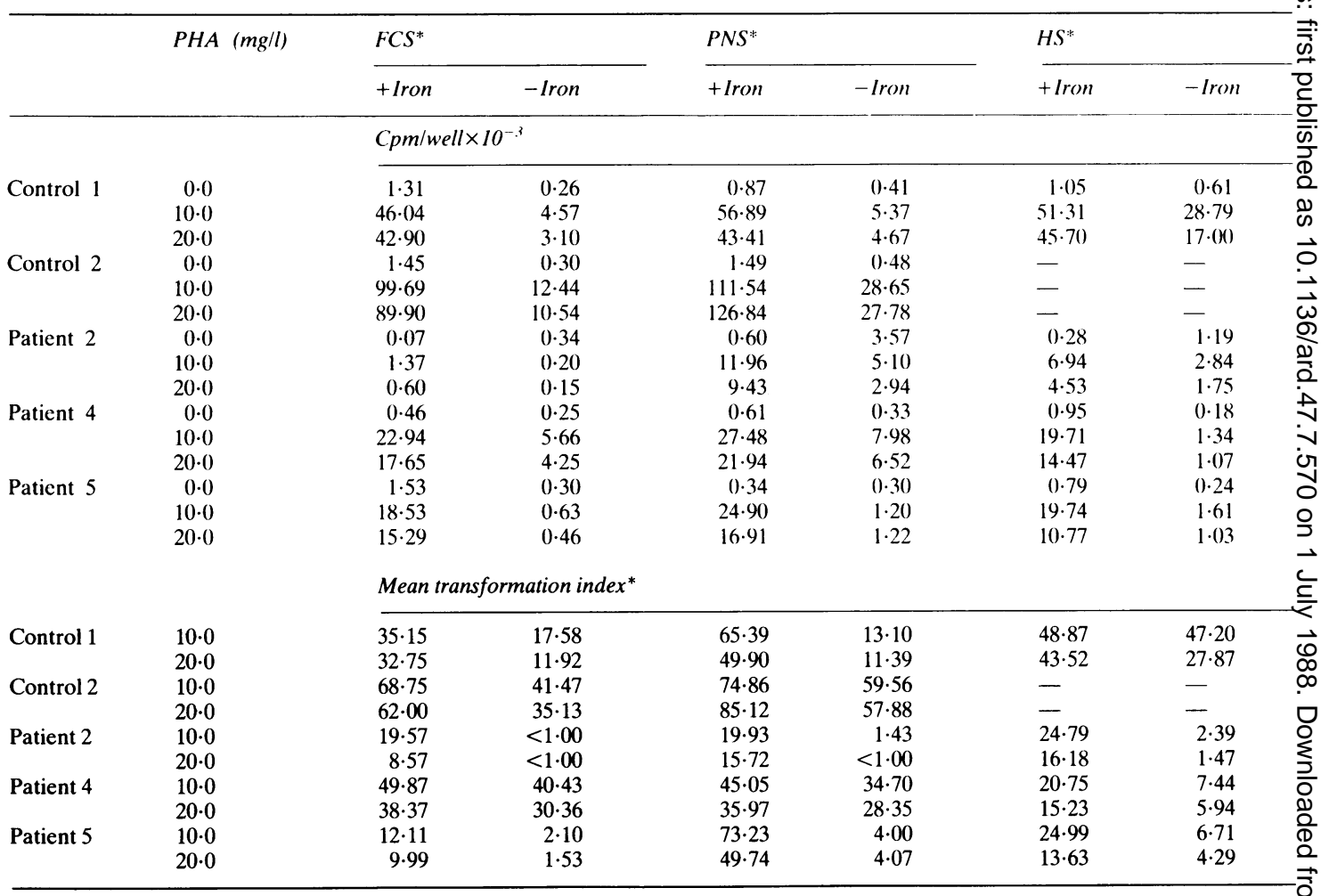

${ }^{*} \mathrm{FCS}=10 \%$ fetal calf serum in RPMI 1640 with antibiotics; PNS $=10 \%$ pooled normal serum in RPMI 1640 with antibiotics; HS $=10 \% \cong$ homologous serum in RPMI 1640 with antibiotics; mean transformation index $=\mathrm{cpm}$ per well after stimulation with $\mathrm{mitogen} / \mathrm{cpm}$ per well without mitogen.

was markedly reduced for lymphocytes from both patients $(\mathrm{p}<0.0001)$ and controls $(\mathrm{p}<0 \cdot 001 ;$ Table 2$)$. Similar reductions were seen for each medium individually in the patients $(\mathrm{p}<0.05)$, and for fetal calf and pooled normal serum in the controls $(p<0 \cdot 05)$. These changes remained significant when the mean transformation indices were calculated (Table 2). The reduction of spontaneous, unstimulated proliferation of lymphocytes by the iron deficient conditions was greater than that of the PHA transformed cells, which resulted in mean transformation indices that were actually higher in iron deficient than in iron containing media. Addition of pooled normal serum resulted in the greatest DNA synthesis for most patients and controls in both iron containing $(p<0.05)$ and iron deficient media, but there was no difference between media containing homologous sera or fetal calf sera. Native iron deficient serum from three patients with rheumatoid arthritis led to a significant reduction in the uptake of $\left[{ }^{3} \mathrm{H}\right]$ thymidine by lymphocytes from a normal subject $(\mathrm{p}<0 \cdot 01)$, which was reversed by prior addition of iron to the serum samples. The mean transformation indices were, however, greater in the iron deficient than in the iron containing media $(\mathrm{p}<0 \cdot 05$; Table 3$)$.

Table 3 Effects of patients' serum on 'normal' lymphocytes

\begin{tabular}{|c|c|c|c|c|c|c|}
\hline \multirow{2}{*}{$\begin{array}{l}P H A \\
(m g / l)\end{array}$} & \multicolumn{2}{|c|}{ Patient 2} & \multicolumn{2}{|c|}{ Patient 4} & \multicolumn{2}{|c|}{ Patient 5} \\
\hline & +Iron & Native* & +Iron & Native & +Iron & Native \\
\hline & \multicolumn{6}{|c|}{ Cpm/well $\times 10^{-3}$} \\
\hline 0.0 & $1 \cdot 14$ & $0 \cdot 34$ & 0.95 & 0.45 & 0.98 & $0 \cdot 37$ \\
\hline $10 \cdot 0$ & $84 \cdot 21$ & $58 \cdot 84$ & $113 \cdot 52$ & $71 \cdot 80$ & $113 \cdot 28$ & $55 \cdot 36$ \\
\hline \multirow[t]{2}{*}{$20 \cdot 0$} & $75 \cdot 00$ & $47 \cdot 55$ & $120 \cdot 11$ & $53 \cdot 41$ & $117 \cdot 90$ & $56 \cdot 07$ \\
\hline & \multicolumn{6}{|c|}{ Mean transformation index* } \\
\hline $10 \cdot 0$ & $73 \cdot 87$ & $173 \cdot 06$ & $119 \cdot 49$ & $159 \cdot 56$ & $115 \cdot 59$ & $149 \cdot 62$ \\
\hline $20 \cdot 0$ & $65 \cdot 79$ & $139 \cdot 85$ & $126 \cdot 43$ & $118 \cdot 69$ & $120 \cdot 31$ & $151 \cdot 54$ \\
\hline
\end{tabular}

${ }^{*}$ Native =native patient serum in iron deficient RPMI 1640; mear transformation index $=\mathrm{cpm}$ per well after stimulation with mitogen cpm per well without mitogen. 
Table 4 Transformation of lymphocytes with increasing doses of phytohaemagglutinin (PHA) RPMI 1640 medium containing $10 \%$ fetal calf serum with iron and antibiotics

\begin{tabular}{|c|c|c|c|c|c|c|c|c|c|}
\hline \multirow[t]{2}{*}{$P H A(m g / l)$} & \multicolumn{9}{|c|}{ Cpm/well $\times 10^{-3}$} \\
\hline & 0.00 & 1.00 & $2 \cdot 50$ & $5 \cdot 0$ & $10 \cdot 0$ & $20 \cdot 0$ & $30 \cdot 0$ & $40 \cdot 0$ & $50 \cdot 0$ \\
\hline Control 1 & $0 \cdot 10$ & $0 \cdot 10$ & $4 \cdot 32$ & $36 \cdot 3$ & $99 \cdot 4$ & $81 \cdot 1$ & $73 \cdot 8$ & $44 \cdot 6$ & $38 \cdot 4$ \\
\hline Control 2 & 0.09 & $0 \cdot 10$ & $2 \cdot 07$ & $54 \cdot 2$ & $84 \cdot 9$ & $79 \cdot 1$ & $78 \cdot 0$ & $76 \cdot 9$ & $75 \cdot 3$ \\
\hline Patient 1 & $0 \cdot 10$ & 0.26 & 1.08 & $12 \cdot 4$ & $51 \cdot 0$ & $144 \cdot 4$ & - & - & - \\
\hline Patient 2 & $0 \cdot 18$ & 0.26 & $2 \cdot 24$ & $4 \cdot 4$ & $50 \cdot 4$ & $55 \cdot 6$ & $58 \cdot 4$ & $38 \cdot 4$ & $29 \cdot 5$ \\
\hline Patient 3 & 0.09 & 0.09 & 0.87 & 4.0 & $15 \cdot 6$ & $39 \cdot 7$ & - & - & - \\
\hline Patient 4 & $0 \cdot 19$ & $0 \cdot 27$ & 0.52 & $7 \cdot 8$ & $26 \cdot 9$ & $64 \cdot 8$ & $70 \cdot 0$ & $30 \cdot 3$ & $31 \cdot 1$ \\
\hline Patient 5 & $0 \cdot 14$ & $0 \cdot 25$ & 1.84 & $11 \cdot 2$ & $58 \cdot 5$ & $103 \cdot 5$ & $88 \cdot 8$ & $58 \cdot 5$ & $58 \cdot 7$ \\
\hline
\end{tabular}

In iron containing RPMI 1640 medium with $10 \%$ FCS and antibiotics lymphocytes from all subjects underwent transformation when treated with PHA (Fig. 1), with no significant differences between cells

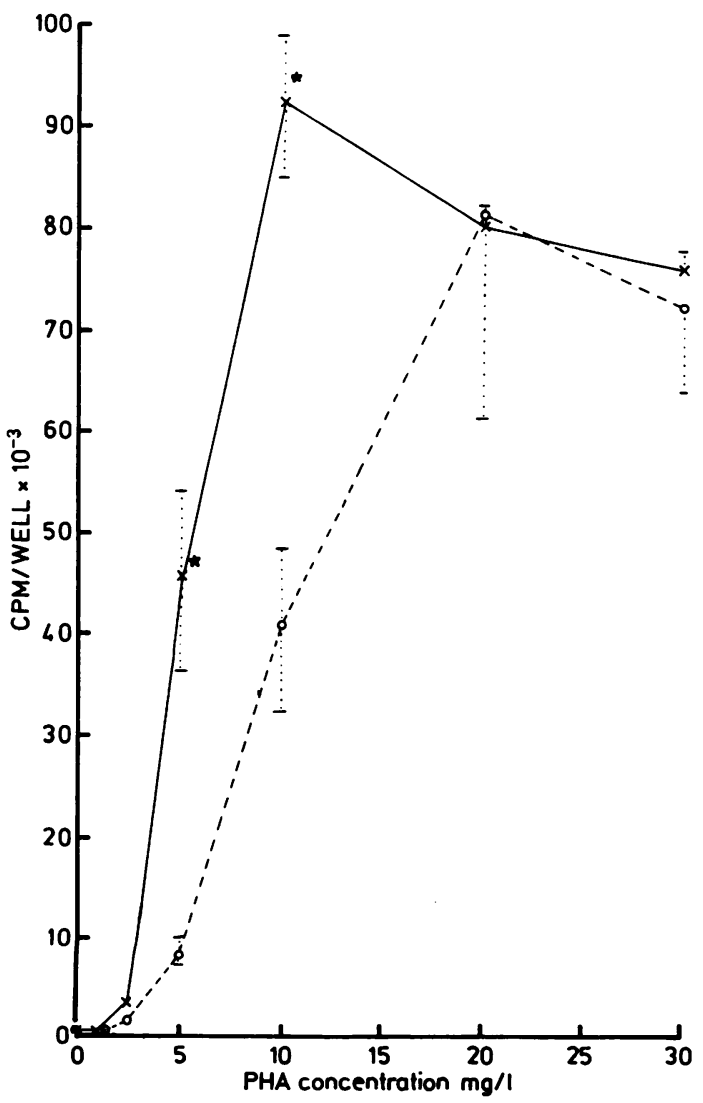

Fig. 1 Dose response curves showing $\left[{ }^{3} H\right]$ thymidine uptake $\left(\mathrm{cpm} /\right.$ well $\times 10^{-3}$, mean (SEM) at increasing concentrations of PHA for controls $(\times-\times-\times)$ and rheumatoid patients $\left(\mathrm{O}_{-}-\mathrm{O}-\mathrm{O}\right) .{ }^{*}$ Indicates values significantly different from controls, $p<0.02$. from patients and controls when the response to mitogen was characterised by the minimum mitogen concentration eliciting a response $(2.5 \mathrm{mg} / \mathrm{l})$ or by the peak $\left[{ }^{3} \mathrm{H}\right]$ thymidine uptake (Table 4). With PHA concentrations of 5 and $10 \mathrm{mg} / 1$, however, there was significantly less response with lymphocytes from the iron deficient rheumatoid patients than from controls $(p<0.02)$, resulting in a reduction in the cumulative $\left[{ }^{3} \mathrm{H}\right]$ thymidine uptake up to PHA concentrations of $20 \mathrm{mg} / 1(p<0.05)$, though by a concentration of $50 \mathrm{mg} / \mathrm{l}$ this was no longer seen. There was no correlation between responsiveness to PHA and degree of iron deficiency in these patients.

\section{Discussion}

Iron deficiency has been shown to inhibit markedly the response to PHA of lymphocytes from both rheumatoid patients and controls $(p<0.001)$ without affecting cell viability. Similarly, iron deficient sera from three patients inhibited the transformation of lymphocytes from a normal subject $(p<0.01)$, and this effect was prevented by prior addition of iron to these serum samples.

Similar results were found in in vitro studies, ${ }^{7}$ in which the degree of proliferation to con A of mouse lymphocytes from iron deficient and normal animals in serum free medium containing apotransferrin was significantly lower than in media containing $20 \%$ iron saturated transferrin or $10 \%$ fetal calf serum. Irrespective of the iron status of the animal, proliferation of cells was lower in media supplemented with serum from iron deficient mice than when serum from normal or iron replete mice was used. The addition of iron to the iron deficient serum also significantly improved its ability to promote proliferation, whereas in vivo repletion of iron deficient mice resulted in restoration of normal lymphocyte responsiveness to con $\mathrm{A}$. Human studies have also shown a decreased in vitro proliferation of lymphocytes from iron deficient patients using media supplemented with their own sera. ${ }^{17} 18$ 
In the present study lymphocytes from iron deficient rheumatoid patients, when incubated in iron containing media, respond to stimulation with PHA in a similar manner to cells from normal subjects, particularly with regard to the minimum mitogen concentration eliciting a response and the peak $\left[{ }^{3} \mathrm{H}\right]$ thymidine uptake. With lower PHA concentrations, however, the proliferation of lymphocytes from patients was reduced, resulting in a significantly lower cumulative $\left[{ }^{3} \mathrm{H}\right]$ thymidine incorporation $(\mathrm{p}<0.05)$. This would be consistent with an intrinsic defect in the patient's cells which is partially inhibiting the proliferative response to PHA. A reduction in the number or affinity of lectin binding sites, reduced interleukin 2 production, or reduced binding to interleukin 2 receptors is possible, though it is unclear at present whether such changes occur consistently in rheumatoid arthritis. ${ }^{19}$ The role of transferrin and its receptor in lymphocyte proliferation is well known, ${ }^{20}$ and although activation antigens were not examined in the present study, others have shown an increase in the number of rheumatoid inflammatory $\mathrm{T}$ cells that express transferrin receptors. ${ }^{21}$ Failure of expression of this receptor is, therefore, unlikely to account for the diminished response to PHA seen in the present study. At a cellular level iron is an essential cofactor for the enzyme ribonucleotide reductase, which is required for the production of deoxyribonucleoside diphosphates in the synthesis of DNA, ${ }^{22}{ }^{23}$ and indeed clinical studies have shown a reduction in the metabolites of deoxyribonucleoside diphosphates in iron deficient patients. ${ }^{24}$

In other studies into PHA induced lymphocyte responsiveness in rheumatoid arthritis it has been stressed that inhibition of proliferation is best shown by examining dose response curves, calculated from the cumulative $\left[{ }^{3} \mathrm{H}\right]$ thymidine uptake at all concentrations of mitogen, rather than the response to specific concentrations, ${ }^{2}$ and that impaired responsiveness is associated with disease activity ${ }^{3}$ and particularly with erosive arthropathy. ${ }^{2}$ Unfortunately, in these studies there is no mention of the iron status of the patients, though it is known that iron deficiency is common in rheumatoid patients and that this correlates with disease activity. ${ }^{9}$ Awareness of the role of iron deficiency in PHA induced lymphocyte transformation is particularly relevant in studies where autologous serum is added to the media, ${ }^{1}$ as lack of iron in this serum will exacerbate the effect of any intrinsic cellular defect.

In the report by Highton and colleagues lymphocyte responsiveness to various mitogens in rheumatoid patients returned to normal after 15-24 weeks' treatment with sodium aurothiomalate, and it was suggested that this was due to lessening of rheuma- toid disease activity. ${ }^{5}$ These workers found, as in our study, that serum samples from some of the patients were capable of suppressing the function of normal lymphocytes, and that this effect was less apparent after treatment. This suppressive effect di not correlate with concentrations of $\mathrm{C}$ reactive protein or rheumatoid factor, but there was a丹 inverse relation between the responsiveness normal lymphocytes with patient sera and the levet of $\mathrm{Clq}$ binding activity. Although it is possible that immune complexes in serum may be one fact $\overrightarrow{a D}$ leading to suppression of lymphocyte function rheumatoid arthritis, there is no mention of the irom status of these patients before and after their goi treatment, which may provide an alternative explani-1 ation for the observed effects.

Iron deficiency may not be the only factor in the impaired proliferative response to PHA in patien\& with rheumatoid arthritis, but the results of the present study do emphasise the need to include the iron status of patients in the interpretation of results from studies of this type.

We thank Ciba-Geigy for financial support.

\section{References}

1 Lockshin M D, Eisenhauer A C, Kohn R, et al. Cell-mediate immunity in rheumatic diseases. II. Mitogen responses in R SLE, and other illnesses: correlation with T- and B-lymphocy? populations. Arthritis Rheum 1975; 18: 245-50.

2 Silverman H A, Johnson J S, Vaughan J H, McGlamory J e己 Altered lymphocyte reactivity in rheumatoid arthritis. Arthrim Rheum 1976; 19: 509-15.

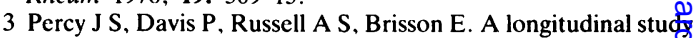
of in vitro tests for lymphocyte function in rheumatoid arthritis Ann Rheum Dis 1978; 37: 416-20.

4 Davis P, Percy J S, Russell A S. In vivo and in vitro effects gold salts on lymphocyte transformation responses and antibod dependent cell-mediated cytotoxicity. $J$ Rheumatol 1979; 527-33.

5 Highton J, Panayi G S, Shepherd P, Griffin J, Gibson $\stackrel{\bigcirc}{\mathrm{P}}$ Changes in immune function in patients with rheumatoide arthritis following treatment with sodium aurothiomalate. An. Rheum Dis 1981; 40: 254-62.

6 Biberfeld G, Nilsson E, Biberfeld P. T lymphocyte subpopul@ tions in synovial fluid of patients with rheumatic diseas Arthritis Rheum 1979; 22: 978-82.

7 Mainou-Fowler T. Brock J H. Effect of iron deficiency on the response of mouse lymphocytes to concanavalin A: the importance of transferrin-bound iron. Immunology 1985; 54: 325-32.

8 Nilsson F. Anaemia problems in rheumatoid arthritis. Acta M Scand 1948; 130 (suppl 210): 1-193.

9 Pitcher C S. Anemia in rheumatoid arthritis. In: Hill A G S, edo Modern trends in rheumatology. Vol. 1 . London: Butterwort ${ }^{\circ}$ 1966: $135-52$.

10 Lawson A A H, Owen E T, Mowat A G. Nature of anaemia rheumatoid arthritis. VII. Storage of iron in rheumato 8 disease. Ann Rheum Dis 1967; 26: 552-9.

11 Muirden K D. The anaemia of rheumatoid arthritis: the significance of iron deposits in the synovial membrang Australasian Annals of Medicine 1970; 2: 97-104. 
12 Ropes M W, Bennett G A, Cobb S, Jacox R, Jessar R A. 1958 Revision of diagnostic criteria for rheumatoid arthritis. Arthritis Rheum 1959; 2: 16-20.

13 Bentley D P, Williams P. Serum ferritin concentration as an index of storage iron in rheumatoid arthritis. J Clin Pathol 1974; 27: 786-8.

14 Bainton D F, Finch C A. The diagnosis of iron deficiency anemia. Am J Med 1964; 37: 62-70.

15 Böyum A. A one-stage procedure for isolation of granulocytes and lymphocytes from human blood. General sedimentation properties of white blood cells in a $1 \mathrm{G}$ gravity field. Scand $J$ Clin Lab Invest 1968; 21 (suppl 97): 77-89.

16 Young D S, Hicks J M. Method for the automatic determination of serum iron. J Clin Pathol 1965; 18: 98-102.

17 Joynson D H M, Jacobs A, Murray Walker D, Dolby A E. Defect of cell-mediated immunity in patients with irondeficiency anaemia. Lancet 1972; ii: 1058-9.

18 Fletcher J, Mather J, Lewis M J, Whiting G. Mouth lesions in iron-deficient anaemia: relationship to Candida albicans in saliva and to impairment of lymphocyte transformation. $J$ Infect Dis 1975; 131: 44-50.
19 Panayi G S. The role of interleukins in the rheumatic diseases. Current Medical Literature on Rheumatology 1987: 6: 37-40.

20 Neckers L M, Cossman J. Transferrin receptor induction in mitogen-stimulated human T lymphocytes is required for DNA synthesis and cell division and is regulated by interlcukin 2 . Proc Natl Acad Sci USA 1983; 80: 3494-8.

21 Waalen K, Forre O, Linker-Israeli M. Thoen J. Evidence of an activated $\mathrm{T}$-cell system with augmented turnover of interleukin 2 in rheumatoid arthritis. Stimulation of human T lymphocytes by dendritic cells as a model for rheumatoid T-cell activation. Scand J Immunol 1987; 25: 367-73.

22 Gräslund A, Ehrenberg A. Thelander L. Characterisation of the free radical of mammalian ribonucleotide reductase. $J$ Biol Chem 1982; 257: 5711-5.

23 Reichard P, Ehrenberg A. Ribonucleotide reductase. A radical enzyme. Science 1983; 221: 514-9.

24 Hoffbrand A V, Ganeshaguru K, Hooton J W L, Tattersall M H N. Effect of iron deficiency and desferrioxamine on DNA synthesis in human cells. Br J Haematol 1976; 33: 517-26. 